\title{
Quantitation of Lactate Dehydrogenase of Developing Molar Teeth of the Mouse
}

\author{
RICHARD W. ROBERTS and DONALD S. STRACHAN \\ School of Dentistry, and Department of Anatomy, School of Medicine, University of Michigan, \\ Ann Arbor, Michigan
}

Of the numerous enzymes existing in multiple molecular forms (isozymes), lactate dehydrogenase has been studied the most extensively. The studies include both clinical and biological investigations on a wide range of tissues and species. ${ }^{1-5}$

The role of lactate dehydrogenase $(\mathrm{LDH})$ in the glycolytic pathway is well known; that is, it mediates the transfer between lactic acid and pyruvate, using nicotinamide adenine dinucleotide $\left(\mathrm{NAD}^{+}\right)$as coenzyme. The isozymic patterns of $\mathrm{LDH}$ in certain tissues have been shown to be related to the development of those tissues. ${ }^{6-8}$ Information on the presence of this enzyme in the tooth, therefore, may provide an insight into the enzymatic mechanisms responsible for the morphologic and chemical changes occurring during the development of the tooth. Recent histochemical investigations $s^{9-12}$ have shown the presence of $\mathrm{LDH}$ in the tooth but do not give either quantitative information on the amount or information on the isozymic composition of the enzyme, or both. This study, therefore, was designed to determine the types and amounts of lactate dehydrogenase in developing mouse molars during dentinogenesis and amelogenesis.

\section{Materials and Methods}

Lactate dehydrogenase activity in first molar teeth was studied by a quantitative assay and by gel electrophoresis. Tissue sections were also prepared to assess the stages of tooth development.

Swiss mice (Webster strain), 2 to 21 days old, were sacrificed at 1-day intervals by

This investigation was supported by USPHS Research Grants 5 SO1 FR-5321, Division of Research Facilities and Resources, and DE-01923-03 from the National Institute of Dental Research, National Institutes of Health, Bethesda, Md.

Received for publication June 8, 1966. decapitation. Heads of mice from two litters were fixed in 10 percent neutral buffered formalin and decalcified. Serial sections of the mandible and maxillas were cut at $10 \mu$ and stained with hematoxylin and eosin to observe the stage of development and the amounts of enamel and dentin formation. The widest section of enamel and dentin on the mesiobuccal surface of the first molar teeth was measured with an ocular micrometer.

Maxillary and mandibular tooth buds from 200 first molars were enucleated, weighed, and homogenized, adding $0.2 \mathrm{ml}$. of distilled water for each milligram of tissue. The samples were analyzed for LDH activity by a spectrophotometric assay at $340 \mathrm{~m} \mu$ and $37^{\circ} \mathrm{C}$. The reaction mixture contained $0.25 \mathrm{ml}$. of $0.36 \mathrm{M} \mathrm{L}+$ lactate (sodium salt), $0.10 \mathrm{ml}$. of $0.05 \mathrm{M} \mathrm{NAD}+, 0.9 \mathrm{ml}$. of $0.05 \mathrm{~N}$ tris- $\mathrm{HCl}$ buffer at $\mathrm{pH} 8.9$, and $0.25 \mathrm{ml}$. of the tissue homogenate. Protein concentration was determined by the method of Lowry et al. ${ }^{13}$ Bovine serum albumin* was used as the protein standard.

Homogenates of tooth buds, prepared and obtained on the same days as described, were submitted to acrylamide gel electrophoresis according to the method described by Ornstein $^{14}$ and Davis. ${ }^{15}$ The homogenates first were diluted with 40 percent sucrose solution to a tissue concentration of $5 \mathrm{mg}$. $/ 0.1$ $\mathrm{ml}$. For each gel, $0.1 \mathrm{ml}$. of this dilution, which contained $5 \mathrm{mg}$. of tissue, was applied directly onto the spacer gel. Sample gel was not used in this procedure. Electrode buffer was layered over the sucrose-sample mixture before the tubes were inserted into the electrophoretic apparatus. A tissue concentration of $5 \mathrm{mg}$. was chosen, because higher concentrations produced smeared bands on the gels and lower concentrations did not

*Armour Company, Chicago, Ill. 
demonstrate the bands of lower activity, as in the older tooth buds.

The gels were stained for LDH activity by a nitro-blue tetrazolium staining reaction modified from a technic of Dewey and Conklin. ${ }^{16}$ This technic leads to deposition of a blue formazan dye in the gel at sites of LDH activity. The reaction mixture contained 9.0 $\mathrm{ml}$. of $0.36 \mathrm{M} \mathrm{L}+$ lactate (sodium salt), 20.0 $\mathrm{mg}$. of NAD, $8.0 \mathrm{mg}$. of phenazine methosulfate, $5.0 \mathrm{mg}$. of nitro-blue tetrazolium, and $57.0 \mathrm{ml}$. of $0.2 \mathrm{M}$ tris- $\mathrm{HCl}$ buffer at $\mathrm{pH} 8.0$. The gels were incubated in the dark at $24^{\circ} \mathrm{C}$. In addition to the tooth buds, homogenates of mouse heart muscle, liver tissue, kidney tissue, skeletal muscle, and serum were analyzed in the same manner.

\section{Results}

Measurements of the enamel and dentin width were found to be a convenient way to assess the stages of amelogenesis. Enamel width increased from 2 to 8 days (Fig. 1). After 8 days, the enamel was composed almost entirely of calcified material and was lost through decalcification prior to sectioning. These results were from mice of the same litter, sacrificed at 1-day intervals. From 2 to 21 days, the width of dentin increased (Fig. 2). The results for days 2 to 11 were from one litter, and those for days 12 to

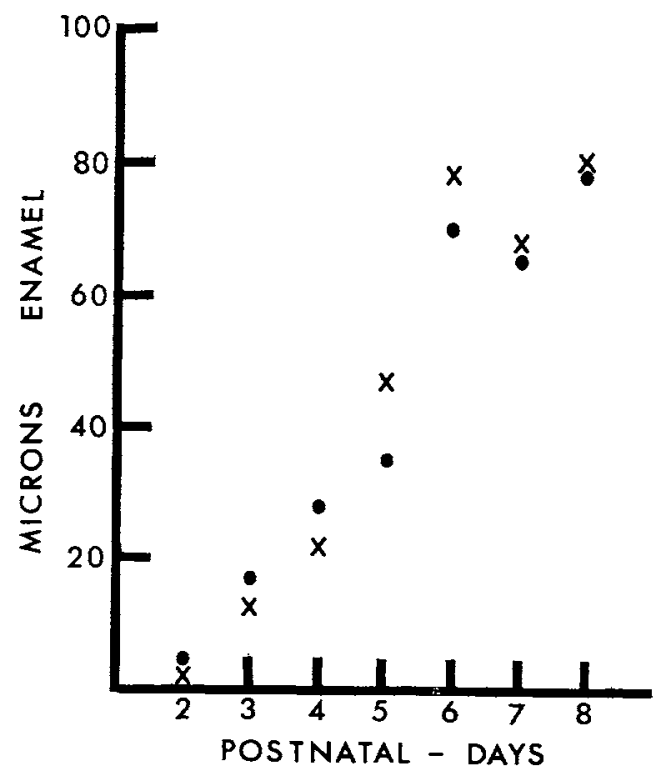

FIG. 1.-Width of enamel (measured in microns), related to age in days. $x=$ Max.; $\bullet=$ mand.

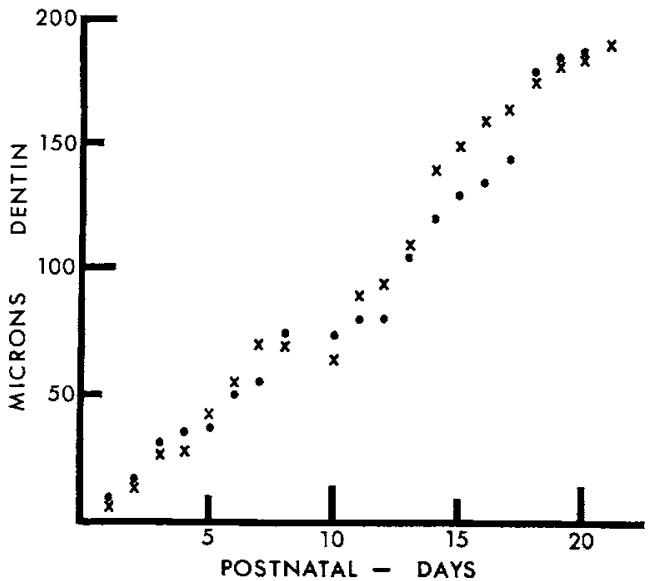

FIG. 2.-Width of dentin (measured in microns), related to age in days. $\mathrm{x}=\mathrm{Max}$; $\bullet=$ mand.

21 were from a second litter. As the enamel and dentin width increased with age, the weight of the first molar teeth increased (Fig. 3). The weights of the teeth varied

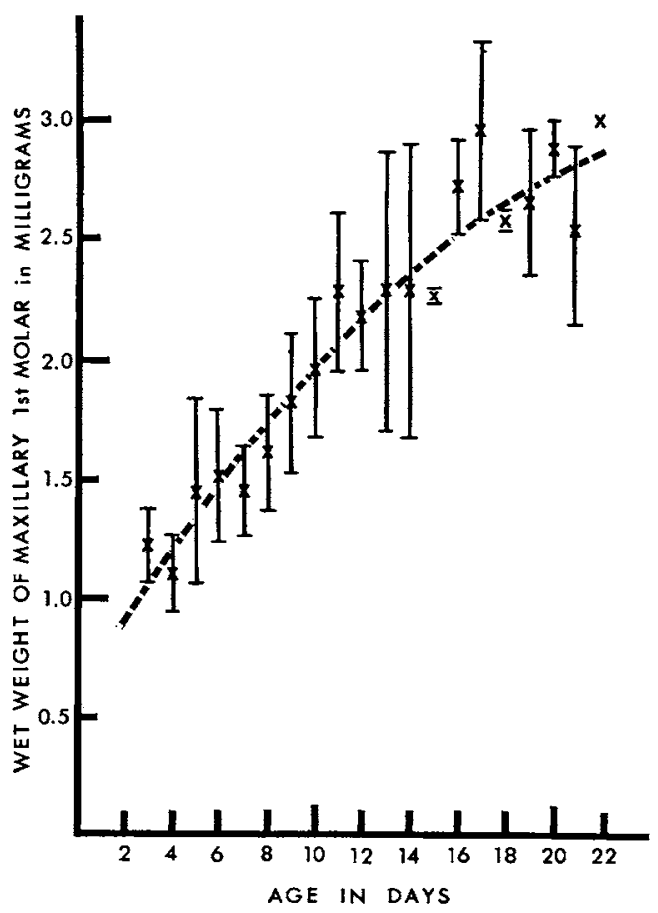

Fic. 3.-Wet weight of the tooth (measured in milligrams), related to age in days. " $\mathrm{X}$ " signifies the mean, and the bar relates to 1 standard deviation on each side of the mean. $r=0.873$; least squares equation: $\mathrm{y}=57.5+16.7 \times-0.29 \mathrm{x}^{2}$; $\mathrm{N}>747$ 


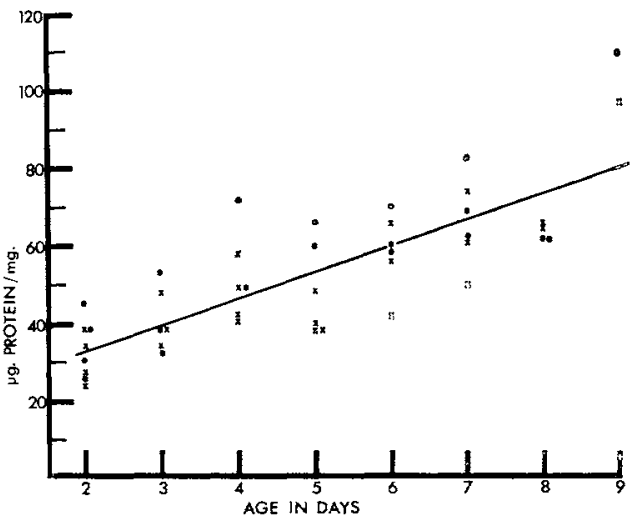

FIG. 4.-Micrograms of protein per milligram of wet weight of tooth, related to age in days. $x=$ $\max$; $\bullet=$ mand.; $r=0.805$; least squares equation: $\mathrm{y}=19.1+6.86 \mathrm{x}$

from 0.8 to $3.3 \mathrm{mg}$. A quadratic equation was computed by the method of least squares to provide a mathematical generalization for the increase in weight. The coefficient of correlation for this increase was 0.873 . Protein concentration of first molar teeth, measured in micrograms of protein per milligram of wet weight of tissue increased during days 2 to 9 (Fig. 4). A linear equation was computed by the least squares method to determine the amount of increase. The linear coefficient of correlation for this increase was 0.805 . These data provide a frame of reference for, and estimate the rate of, these parameters during mouse molar tooth development.

Lactate dehydrogenase activity, measured in millimicromoles of reduced $\mathrm{NAD}^{+}$ (NADH) formed per minute per milligram of wet weight of tissue, decreased with increasing age of the mouse (Fig. 5). The $\mathrm{LDH}$ activity, measured in millimicromoles of NADH formed per minute per microgram of protein of the tooth, decreased during days 2 to 9 (Fig. 6). In both activities, there was considerable variation in each day's measurements. A specific cause of this variance was not found. A linear equation was computed by the least squares method to determine the amount of decrease during days 2 to 9 . The linear coefficient of correlation for this decrease was -0.809 .

Five $\mathrm{LDH}$ isozymes from tooth buds were demonstrated after acrylamide gel electrophoresis (Fig. 7). The LDH isozymes are numbered LDH-1, LDH-2, LDH-3, LDH-4,

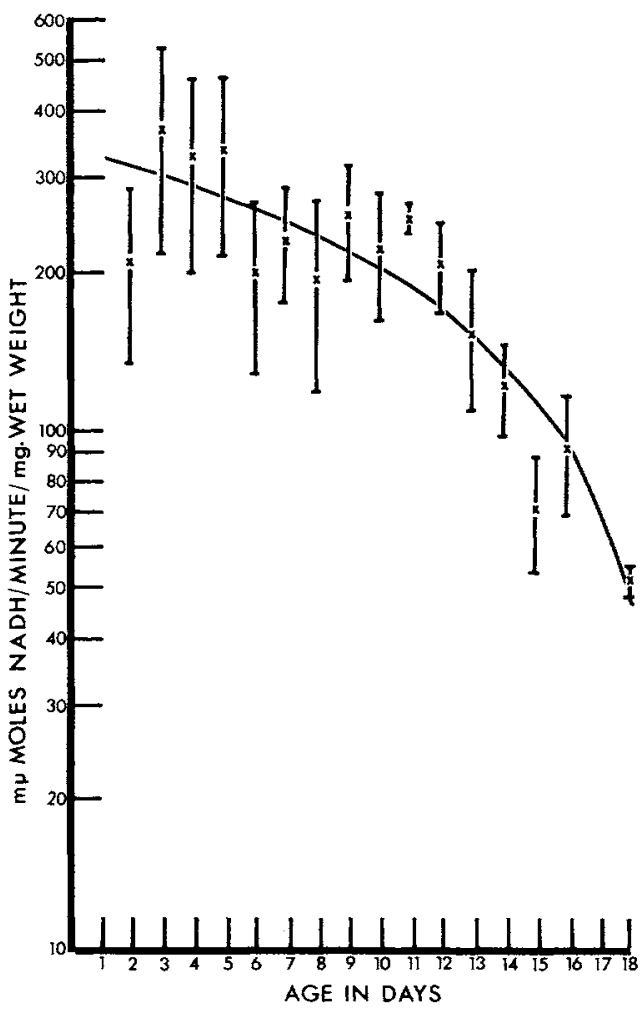

FIG. 5.-Millimicromoles of NADH formed per minute per milligram of wet weight of tooth, related to age in days. " $\mathrm{X}$ " signifies the mean, and the bar relates to one standard deviation on each side of the mean. $\mathrm{x}=\max$; $\bullet=$ mand.; least squares equation: $\mathrm{y}=110.4+-10.53 \mathrm{x}$

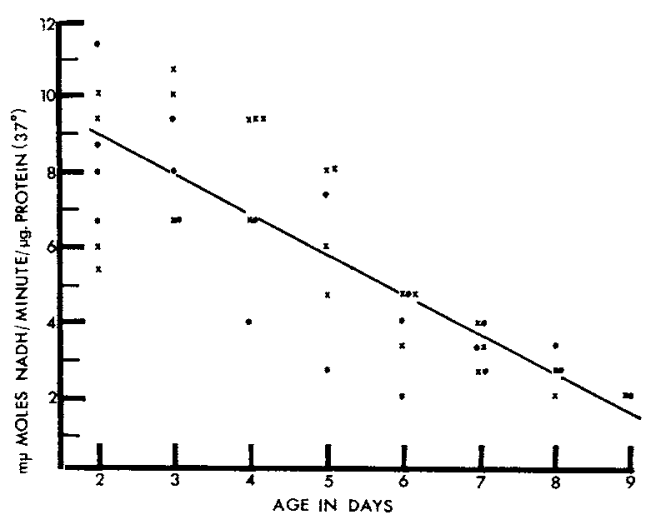

Fig. 6.-Millimicromoles of $\mathrm{NADH}$ formed per minute per microgram of protein of the tooth. 


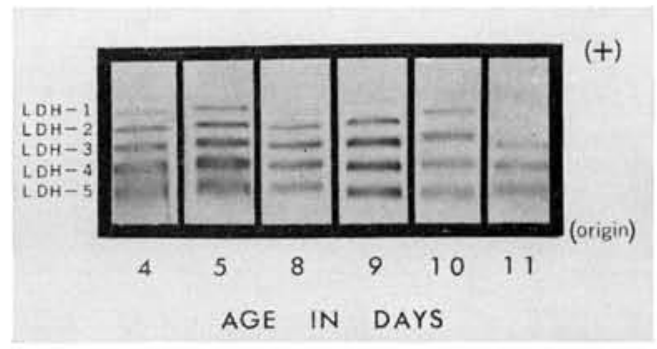

FIG. 7.-Lactate dehydrogenase isozymes of developing molar teeth demonstrated by acrylamide gel electrophoresis. Five isozymes are present (LDH-1, LDH-2, LDH-3, LDH-4, and LDH-5). With increasing age, the most fast-moving isozymes (LDH-1 and LDH-2) are not demonstrated and the overall density of all the bands decreases.

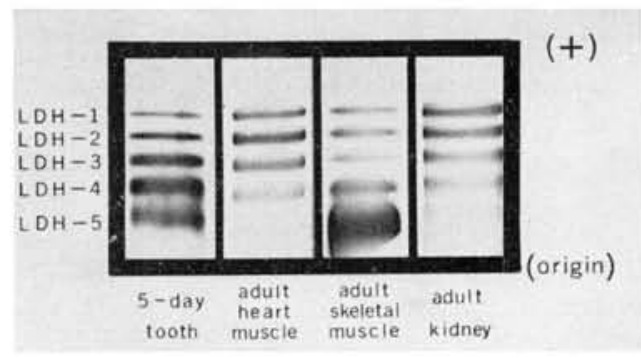

FIc. 8.- Lactate dehydrogenase isozymes of developing 5-day molar teeth compared with other tissues of the mouse (adult heart muscle, adult kidney, and adult skeletal muscle).

and LDH-5 from the anode to the cathode. At days 2 through 7, five bands of $\mathrm{LDH}$ activity were demonstrated. With increasing age, $\mathrm{LDH}-1$ and $\mathrm{LDH}-2$ decreased in activity (Fig. 7). A decrease in the overall density of all the isozymes occurred with increasing age.

The lactate dehydrogenase isozymes demonstrated in mouse first molar teeth were identical in electrophoretic mobility to the isozymes from mouse heart muscle, liver, kidney, skeletal muscle, and serum (Fig. 8).

\section{Discussion}

The entire sequence of dentin and enamel formation, calcification, and eruption into the oral cavity occurs during days 2 to 21 in the first molar of the mouse. These stages of development have been studied by $\mathrm{Cohn}^{17}$ and are similar to the developmental stages found in this study. The first predentin is found at 1 to 2 days. At 9 to 15 days, enamel maturation occurs. At 17 days, the teeth erupt into the oral cavity and, at 21 to 25 days, are in occlusion. For convenience, we have expressed these stages of mouse molar tooth development in terms of increasing enamel and dentin width, increasing wet weight, and increasing protein content (Fig. 1-4). As these morphologic and developmental changes are occurring, the LDH activity in the tooth decreases, as shown by the quantitative assay and gel electrophoretic analysis. The histochemical evidence of Fullmer, ${ }^{9}$ Mizushima,${ }^{10}$ and Nuki and Bonting ${ }^{11}$ supports this result. On the basis of this information alone, however, it is difficult to establish a cause-and-effect relationship between the amount of lactate dehydrogenase and the developmental sequence.

Lactate dehydrogenase is ubiquitious to all tissues, and it is found with varying amounts and with varying composition of the isozymes. The five isozymes are composed of two different components, each under the control of a separate genetic site and having different physiologic roles, as has been stated by Kaplan ${ }^{18}$ and by Markert. ${ }^{19}$ Each isozyme is thought to be a tetramer. The " $M$ " component, so designated because it is found primarily in skeletal muscle, produces the strongest bands at the LDH-5 position. This component has been found to operate well at high pyruvate concentrations, anaerobically, to produce lactate. The second, or " $\mathrm{H}$ " component, which produces strong bands in the LDH-1 and LDH-2 positions, is found typically in heart muscle. It functions best in low pyruvate concentrations, in aerobic situations, to favor oxidation of pyruvate via the Krebs cycle. Markert $^{19}$ has suggested that the genetic control of the synthesis of these two components of lactate dehydrogenase is influenced by the oxygen tension in the cells. The isozyme patterns of developing teeth shown here suggest that the oxygen tension in these cells decreases with age.

More information about the regulating mechanisms, the genetic control of synthesis, and the cytologic localization of this enzyme in the numerous cell components of the developing tooth is prerequisite to understanding what role LDH plays in tooth development and calcification. In addition, lactate dehydrogenase is only one of the many dehydrogenases concerned with the oxidative metabolism of cells. It may be necessary to 
study these other dehydrogenases before the total metabolic scheme is understood.

\section{Summary}

Homogenates of developing first molar teeth of 2- to 21-day-old mice were analyzed by a quantitative spectrophotometric technic and by acrylamide gel electrophoresis for lactate dehydrogenase activity. Tissue sections of these teeth were also prepared, and the enamel and dentin widths were measured. The protein content of the teeth was determined and the wet weights were recorded. The enamel and dentin widths, the wet weight, and the protein content all increased with increasing age of the tooth, expressing the stages of mouse molar development. Lactate dehydrogenase activity, measured in millimicromoles of NADH formed per minute per milligram of wet weight of tissue and in millimicromoles of $\mathrm{NADH}$ formed per minute per microgram of protein, decreased with increasing age of the tooth. Five lactate dehydrogenase isozymes from the teeth were demonstrated after acrylamide gel electrophoresis. With increasing age of the tooth, there was a decrease in the activity of all the isozymes. After 10 days, the two most fast-moving isozymes could not be demonstrated. The LDH isozymes were identical in electrophoretic mobility to the isozymes from mouse heart muscle, liver, kidney, skeletal muscle, and serum. At present, an exact role and mechanism of lactate dehydrogenase in the developing tooth cannot be defined.

The authors acknowledge the technical assistance of Mr. Walter Secosky, Mrs. Antoinette Levine, and Mr. Howard Tirshwell.

\section{References}

1. Hunter, R. L., and Markert, C. I. Histochemical Demonstration of Enzymes Separated by Zone Electrophoresis in Starch Gel, Science, 125: $1294,1957$.

2. Markert, C. L., and Moller, F, Multiple Forms of Enzymes: 'issue, Ontogenetic, and Species Specific Patterns, Proc. nat. Acad. Sci. (Wash.), 5:753-63, 1959.

3. Vesell, E. S., and BeArN, A. G. Localization of LDH Activity in Serum Fractions, Proc. Soc, exp. Biol. (N.Y.), 94:96-99, 1957.

4. Nebel, E. J., and Conktis, J. L. Development of Lactic Dehydrogenase Isozymes in the Chick Embryo, Proc. Soc, exp. Biol. (N.Y.), 115:532-46, 1964.

5. Wroblewski, F, and Gregory, K. F. Lactic Dehydrogenase Isozymes and Their Distribution in Normal Tissues and Plasma and in Disease States, Ann. New York Acad. Sci., 94:912,31, 1961.

6. Markert, C. L., and URsPrung, H. The Ontogeny of Isozyme Patterns of Lactate Dehydrogenase in the Mouse, Develop. Biol., 5:363-81, 1962.

7. CaHN, R. D., Kaplan, N. O., Levine, L., and ZwILling, E, Nature and Development of Lactic Dehydrogenase, Science, 136:962-69, 1962.

8. Lindsay, D. T. Isozymic Patterns and Properties of Lactate Dehydrogenase from Developing Tissues of the Chicken, $J$, exp. Zool., 152:75-89, 1963.

9. Fullmer, H. M. Dehydrogenases in Developing Teeth of Rats, J. Hisiochem. Cytochem., 11:(5) $641-44,1963$

10. Mizushima, $\dot{T}$. Histochemical Studies of Dehydrogenases in the Developing Teeth, Histochem. Meth., 3:538-51, 1964.

11. NukI, K., and Bonting, S. L. Quantitative Histochemistry of the Developing Hamster Tooth: Alkaline Phosphatase and Lactic Dehydrogenase, $J$. Histochem. \&. Cytochem., 9:117-25, 1961.

12. BALOGH, K. Histochemical Study of Oxidative Enzyme Systems in Teeth and Peridental Tissues, J. dent. Res., 42:1457-66, 1963.

13. Lowry, O. H., Rosenbrough, N I FArR, A. L and Randali, R. J. Protein Measurement with the Folin Phenol Reagent, J. biol. Chem., 193: $265-75,1951$

14. ORnstein, L. Disc Electrophoresis. I. Background and Theory, Ann. New York Acad. Sci., $121: 321$ 49,1964

15. Davis, B. J. Disc Electrophoresis. II. Method and Application to Human Serum Proteins, Ann. New York Acad. Sci, 121:404-27, 1964.

16. Dewey, M. M., and Conkin, J. L. Starch Gel Electrophoresis of Lactic Dehydrogenase from Rat Kidney, Proc. Soc. exp. Biol. (N. Y.), 105:49294,1960

17. Corn, S. A. Development of the Molar Teeth in the Albino Mouse, Amer. J. Anat., 101:295-319, 1957.

18. KapLAN, N. O. Studies on Molecular Evolution with Pyridine Coenzyme Analogs. In Proceedings of the Fifth International Congress on Biochemistry, HI, Oxford, Pergamon Press, 1963, p. 97101 .

19. Markert, C. L. Epigenetic Control of Specific Protein Synthesis in Differentiating Cells. In Cytodifferential and Macromolecular Synthesis, New York, N.Y., Academic Press, Inc., 1963, p. 65-84. 